\title{
Colonic tumour presenting as discrete upper abdominal mass
}

\author{
Benjamin Hamilton, ${ }^{1}$ Chun Lap Pang, ${ }^{2}$ Tarig Adlan ${ }^{2}$
}

${ }^{1}$ Department of General Surgery, Royal Devon \& Exeter Hospital, Exeter, Devon, UK ${ }^{2}$ Department of Radiology, Plymouth Hospitals NHS Trust, Plymouth, Devon, UK

\section{Correspondence to} Dr Benjamin Hamilton, benjamin.hamilton@nhs.net

Accepted 7 August 2015

\section{(a) CrossMark}

To cite: Hamilton $B$ Pang CL, Adlan T. BMJ Case Rep Published online: [please include Day Month Year] doi:10.1136/bcr-2015211311

\section{DESCRIPTION}

A 72-year-old retired museum guide presented with a discrete lump in the right upper quadrant of his abdomen, which he noticed after feeling a pull in his abdomen while heavy lifting several days prior. The lump was firm, tender and warm with overlying erythema, and was reducible on palpation and lying flat. He had no previous abdominal surgery and was clinically well. $\mathrm{He}$ had microcytic anaemia and $\mathrm{C}$ reactive protein of $127 \mathrm{mg} / \mathrm{dL}$. The clinical differential was spontaneous hernia, abscess or haematoma. ${ }^{1}$

An abdominal ultrasound scan (USS) revealed a mobile lesion of mixed echogenicity that resembled a bowel sonographic signature (figure 1). The base of the lesion could not be identified; it appeared to originate from the peritoneum (figure 2), suggestive of a hernia.

A subsequent CT demonstrated a segregated $7 \mathrm{~cm} \times 6 \mathrm{~cm}$ anterior abdominal wall collection, the base of which abutted the peritoneum. Immediately beneath, there was focal mural thickening at the hepatic flexure adhering to the collection (figure 3).

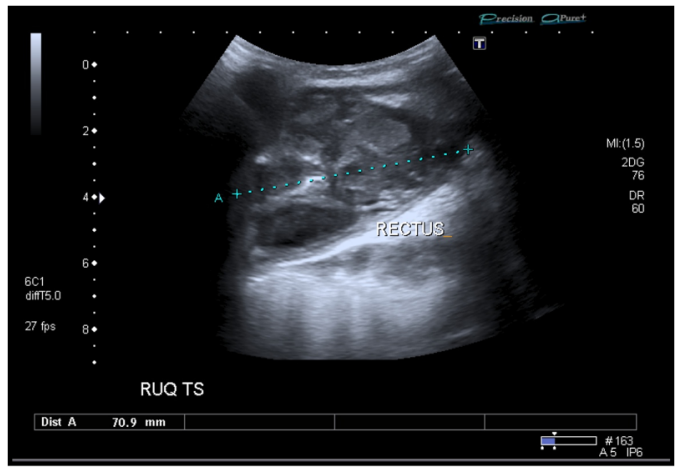

Figure 1 Ultrasound scan transverse view of right upper quadrant anterior abdominal mass.



Figure 2 The lesion does demonstrate peripheral Doppler signal and appears continuous with the peritoneum.

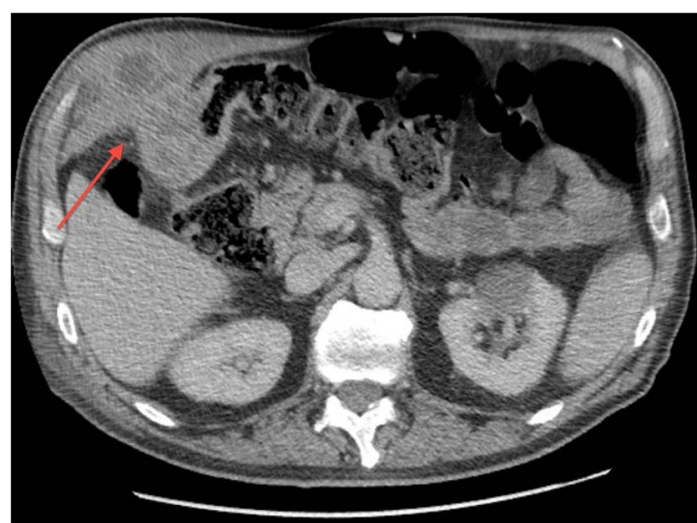

Figure $3 \mathrm{CT}$ of the abdomen, axial slice, demonstrating collection with colonic involvement.

The patient underwent emergency laparotomy, revealing a complex tumour arising from the hepatic flexure with associated enterocutaneous fistula and superficial collection. This was further reported as a moderately differentiated Duke's B adenocarcinoma pT4N0, and the patient went on to receive adjuvant chemotherapy.

This patient had an unusual presentation that was initially suggestive of an abdominal hernia, and, without imaging beyond the initial USS, he was at high risk of perforation, infection or metastasis. ${ }^{23}$

\section{Learning points}

- Ultrasound scan (USS) is a reliable first imaging modality for investigation of abdominal masses with useful diagnostic yield.

- A mass with the appearance of a hernia on USS occurring in an uncommon site with no previous surgical history should be treated with high suspicion.

- Any case of abdominal mass, raised $\mathrm{C}$ reactive protein and microcytic anaemia, should always be worked up to exclude adenocarcinoma.

Acknowledgements The authors thank the patient, the general surgical team and the radiology department.

Contributors $\mathrm{BH}$ researched and wrote the article. CLP identified the case for publication and reported the radiological images. TA provided senior oversight and guidance.

Competing interests None declared.

Patient consent Obtained.

Provenance and peer review Not commissioned; externally peer reviewed. 


\section{REFERENCES}

1 Park AE, Roth JS, Kavic SM. Abdominal wall hernia. Curr Prob/ Surg 2006;43:326-75.
2 Jain N, Goyal N, Mukherjee K, et al. Ultrasound of the abdominal wall: what lies beneath? Clin Radiol 2013;68:85-93.

3 Bashir U, Moskovic E, Strauss D, et al. Soft-tissue masses in the abdominal wall. Clin Radiol 2014:69:e422-31.

Copyright 2015 BMJ Publishing Group. All rights reserved. For permission to reuse any of this content visit

http://group.bmj.com/group/rights-licensing/permissions.

BMJ Case Report Fellows may re-use this article for personal use and teaching without any further permission.

Become a Fellow of BMJ Case Reports today and you can:

- Submit as many cases as you like

- Enjoy fast sympathetic peer review and rapid publication of accepted articles

- Access all the published articles

- Re-use any of the published material for personal use and teaching without further permission

For information on Institutional Fellowships contact consortiasales@bmjgroup.com

Visit casereports.bmj.com for more articles like this and to become a Fellow 